\title{
Description of two new species of Enclisis (Hymenoptera: Ichneumonidae) and support for the secretory role of tyloids in ichneumonid males
}

\author{
SANTIAGO BORDERA and EsTEFANÍA HERNÁNDEZ-RODRÍGUEZ \\ CIBIO (Centro Iberoamericano de la Biodiversidad). Universidad de Alicante. Ap. Corr. 99. 03080-Alicante, Spain; \\ e-mail: s.bordera@ua.es
}

Key words. Ichneumonidae, Cryptinae, Enclisis, new species, taxonomy, key, phenology, secretory glands, tyloids, Spain

\begin{abstract}
Two new species of Enclisis Townes, 1970 from Spain are described and illustrated: E. dichroma sp.n. and E. schwarzi sp.n. The new species are distinguished from the closest species $E$. infernator and $E$. ornaticeps by head and leg characters and body colour. Data on their phenology and a key to these four European species are presented. External and internal scanning electron microscopy of male tyloids revealed that these structures, in both new species, have a secretory role.
\end{abstract}

\section{INTRODUCTION}

Enclisis Townes, 1970 is a small Palearctic genus with only seven species, six from Europe (Schwarz, 1989) and one from China (Schwarz, 1998). The genus belongs to the subtribe Cryptina Townes (Ichneumonidae, Cryptinae, Cryptini) and is characterised, among other features, by the axillus vein parallel and close to the anal margin of hind wing, mediella strongly arched, areolet small and pentagonal, first gastral tergum without a lateral projection at base and propodeal spiracle circular.

Biology of the species is poorly known. A few references indicate they are idiobiont ectoparasitoids of Cerambycidae (Coleoptera) (Schwarz, 1989), Sphecidae (Schwarz, 1989, Jonaitis, 1990) and Chrysididae (Hymenoptera) (Schwarz, 1989), all of which nest in branches or wood.

While studying material collected in oak forests growing along the Mediterranean Spanish coast, two new species of Enclisis were found. These species are closely related to E. infernator (Aubert, 1968) and E. ornaticeps (Thomson, 1885), but can be recognised by head characters, body colour, and other taxonomic features cited in the key presented here. Data on the flight activity of both species are also reported.

Of particular interest is the morphology of male tyloids. These structures are elliptical or linear raised areas on the outer surface of several flagellar segments of male antennae in some ichneumonids. Relative position, number and form of these structures are of taxonomic importance (Townes, 1970; Gauld \& Bolton, 1988; Quicke, 1997 and others). Traditionally, the biological role of the tyloids was assumed to be sensory (Townes, 1970; Gauld, 1991). Observations using scanning electron microscopy have revealed the presence of pores that were suspected to be associated with an olfactory (Frilli, 1974) or gustatory function (Quicke, 1997). Isidoro et al. (1996) suggested that these pores could be for the release of secretions, which a male transfers onto a female's antennae during courtship, thereby enhancing female receptivity. This hypothesis was confirmed by Bin et al.
(1999) studying the ichneumonid, Pimpla turionellae (L.), (Ichneumonidae, Pimplinae), but no other such studies are reported.

In this paper the presence of pores in the male tyloids of Enclisis species are demonstrated. These pores are associated with internal cuticular ducts, which indicate a secretory rather than a sensory function. This discovery, is further support for the hypothesis of Isidoro et al. (1996) concerning the biological role of tyloids in males of Ichneumonidae.

\section{MATERIAL AND METHODS}

Specimens were collected in 1992 by means of Malaise traps placed at two localities near the Mediterranean coast of Spain. The localities were Font Roja (Alcoi, Alicante, 38 39'00' N, $0^{\circ} 31^{\prime} 10^{\prime \prime} \mathrm{W}$ ) and Barranco de Saragutillo (Serra, Valencia, $39^{\circ} 42^{\prime} 53^{\prime} ' \mathrm{~N}, 0^{\circ} 28^{\prime} 20^{\prime \prime} \mathrm{W}$ ). In the former the Malaise trap was at a height of $1200 \mathrm{~m}$ above sea level and functioned from February to October. That at the second locality, at $550 \mathrm{~m}$ above sea level, functioned from February to the end of August when the sampling was interrupted by a fire. In both cases, insects were removed either weekly or fortnightly. For the phenology charts, information for each two weekly periods was combined into a single value.

Type material of the new species is preserved in the Entomological Collection of the University of Alicante (CEUA), in the Museo Nacional de Ciencias Naturales (MNCN, Madrid) and the Schwarz Collection (SC, Linz, Austria). Type specimens of all European species have been studied. This material is in the following collections: Laboratory of Entomology of Wageningen University (The Netherlands), Musée Zoologique (Lausanne, Switzerland), Museum of Natural History of Wroclaw University (Poland), Museum of Zoology of Lund University (Sweden), Natur-Museum Senckenberg (Frankfurt, Germany) and The Natural History Museum (London, United Kingdom). Material from the Schwarz collection (Linz, Austria) was also studied.

Scanning electron microscopy studies were done using an Hitachi S-3000N. For viewing the internal cuticular structure of tyloids, the methodology of Bin et al. (1999) was used modified as follows:

Dry male antennae were treated with warm $10 \%$ potassium hydroxide for 30 minutes, cut in half longitudinally with a razor 


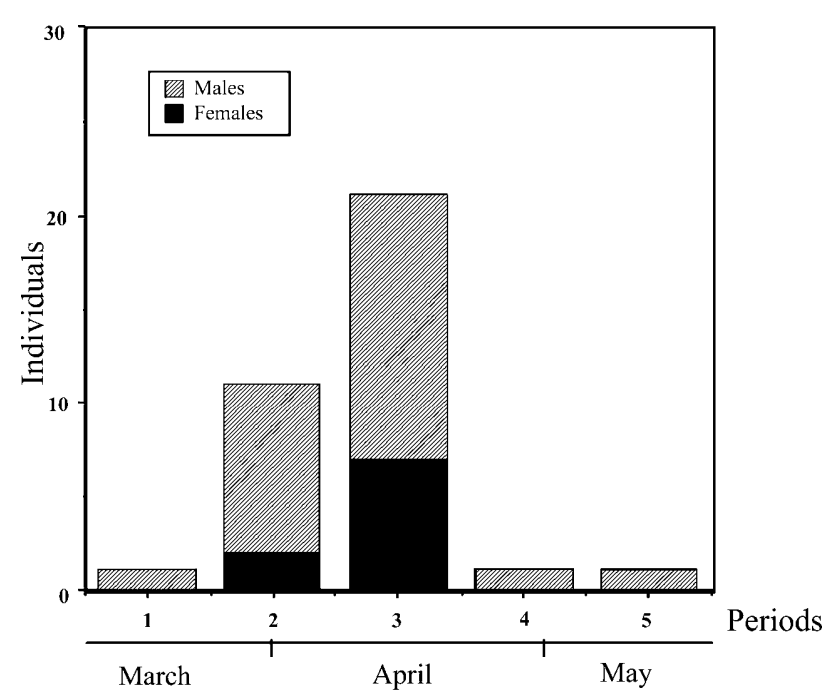

Fig 1. Seasonal activity of adults of E. dichroma sp. n.

blade (only the antennomeres with tyloids to facilitate manipulation), treated again with warm potassium hydroxide for 10 minutes and then washed with distilled water. After dehydration in a graded ethanol series $(40,70,90$ and $100 \%)$, the antennae were critical-point-dried in a Electron Microscopy Sciences EMS 850 apparatus before gold coated for scanning.

Terminology. Terms used for surface sculptures on sclerites were adapted from Eady (1968).

\section{RESULTS}

\section{Enclisis dichroma sp. $\mathbf{n}$.}

(Figs 1, 3-6, 14, 18, 22-26)

Female. Body length (without ovipositor) $4.7-8.6 \mathrm{~mm}$. Head $0.6-0.9 \mathrm{~mm}$ long and $1.0-1.6 \mathrm{~mm}$ wide. Thorax 1.6-2.9 mm long, 0.9-1.5 mm wide (mesoscutum). Front wings $3.8-6.0 \mathrm{~mm}$ long. Petiole $0.5-0.9 \mathrm{~mm}$ long. Postpetiole $0.3-0.6 \mathrm{~mm}$ long and $0.4-0.6 \mathrm{~mm}$ wide. Ovipositor sheaths $2.0-3.5 \mathrm{~mm}$ long.

Coloration. Reddish. Spots on the cheeks close to base of mandibles, mandibular teeth, vertex, occiput and postocciput partially or completely, upper half of temples, oral and occipital carina, basal flagellar segments above, hind edge of propleurum, sutures of meso and metanotum, tegula, sternum between coxae, all coxae partially, trochanters, hind femora above except for 0.2 at the base, and base of petiole black. Gastral segments, except for the central basal area of the second one, fore and middle femora above, tibiae partially and tarsi brown to dark brown. Hind margin of terga 2-3 and palpi usually light brown. Antennae with white marks on the 6-9 flagellar segments. Seventh gastral segment with a white membrane. Wings with transverse dark band.

Description. Head (Fig. 14). Transverse, 1.7-1.8 times as wide as long, strongly constricted behind the eyes. Temple 0.3 times as long as eye (viewed from above). Vertex, frons and face with dense punctures on granulate background. Temples with small and very sparse setiferous punctures on a smooth and polished background. Malar space strongly granulate, about 1.1-1.2 times as wide as basal width of mandible. Clypeus moderately

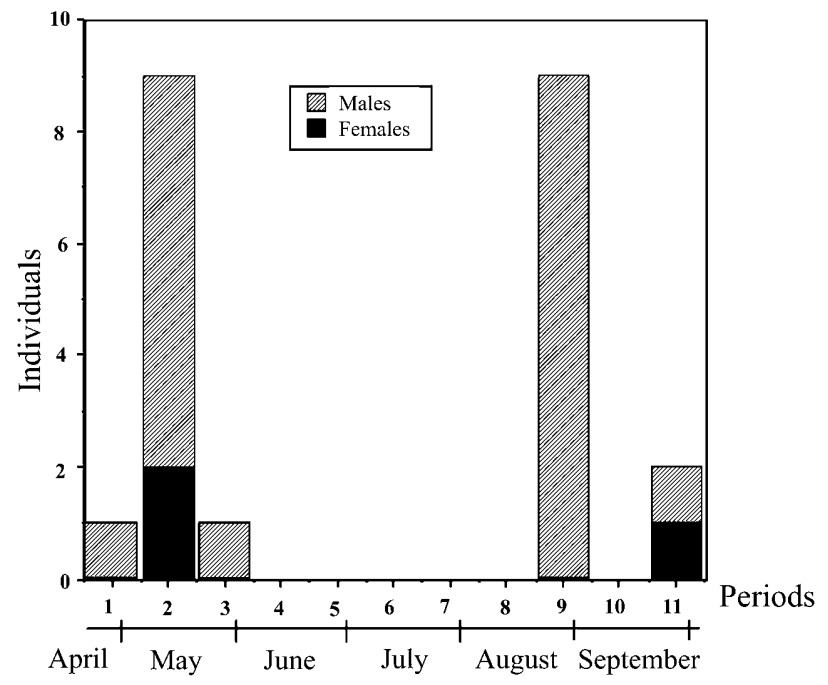

Fig 2. Seasonal activity of adults of E. schwarzi sp. n.

convex and polished, with sparse weak punctures, about 2.2-2.3 times as wide as long, its apical margin straight, with sharp lateral edges and a blunt angulation on midline. Lower mandibular tooth clearly longer than upper tooth. Antennae with 23-25 segments; first flagellar segment 3.6-3.7 times as long as wide (Fig. 18). Genal carina joining oral carina behind base of mandible at a distance of 0.6-0.8 times the basal width of the mandible. Hind ocelli separated from eye about 1.5-1.8 times their diameter. Space between hind ocelli 1.5-1.8 their diameter.

Thorax (Fig. 3). Pronotum weakly strigose on the hind edge. Epomia present. Mesoscutum polished, weakly coriaceous in the centre; weak and very sparse punctures on the lateral lobes, more deep and dense in the centre but always smaller than their interspaces. Notauli deep, reaching about $0.5-0.6$ the distance to scutellum. Scutellar groove with longitudinal carinae. Scutellum smooth and polished, finely punctate and without lateral carinae. Mesopleurum finely rugose on the upper side of sternaulus, except on and in front of the speculum; the background polished with very sparse setiferous punctation, sometimes weakly granulate in the rugose area. Speculum smooth, polished and completely hairless. Sternaulus sinuous, its hind end, weakly downward toward base of middle coxa, only strongly distinct on $2 / 3$ the length of mesopleurum. Metapleurum conspicuously rugose; rest of propodeum weakly rugose or smooth, on a polished or finely granulate background. Both of its transverse carinae strong and complete but the apical transverse carina not forming a sublateral crest. Propodeal spiracle circular and joining pleural carina. Juxtacoxal carina strongly present at least at the base. Ramulus of fore wing absent. Radial cell, 2.8-3.3 times as long as its maximum width. Second recurrent vein weakly inclivous or almost vertical. Areolet small and pentagonal. Nervulus opposite basal vein. Nervelus vertical, strongly angular and intercepted a little below the middle. Hind femora 4.6-4.8 times as long as high. 

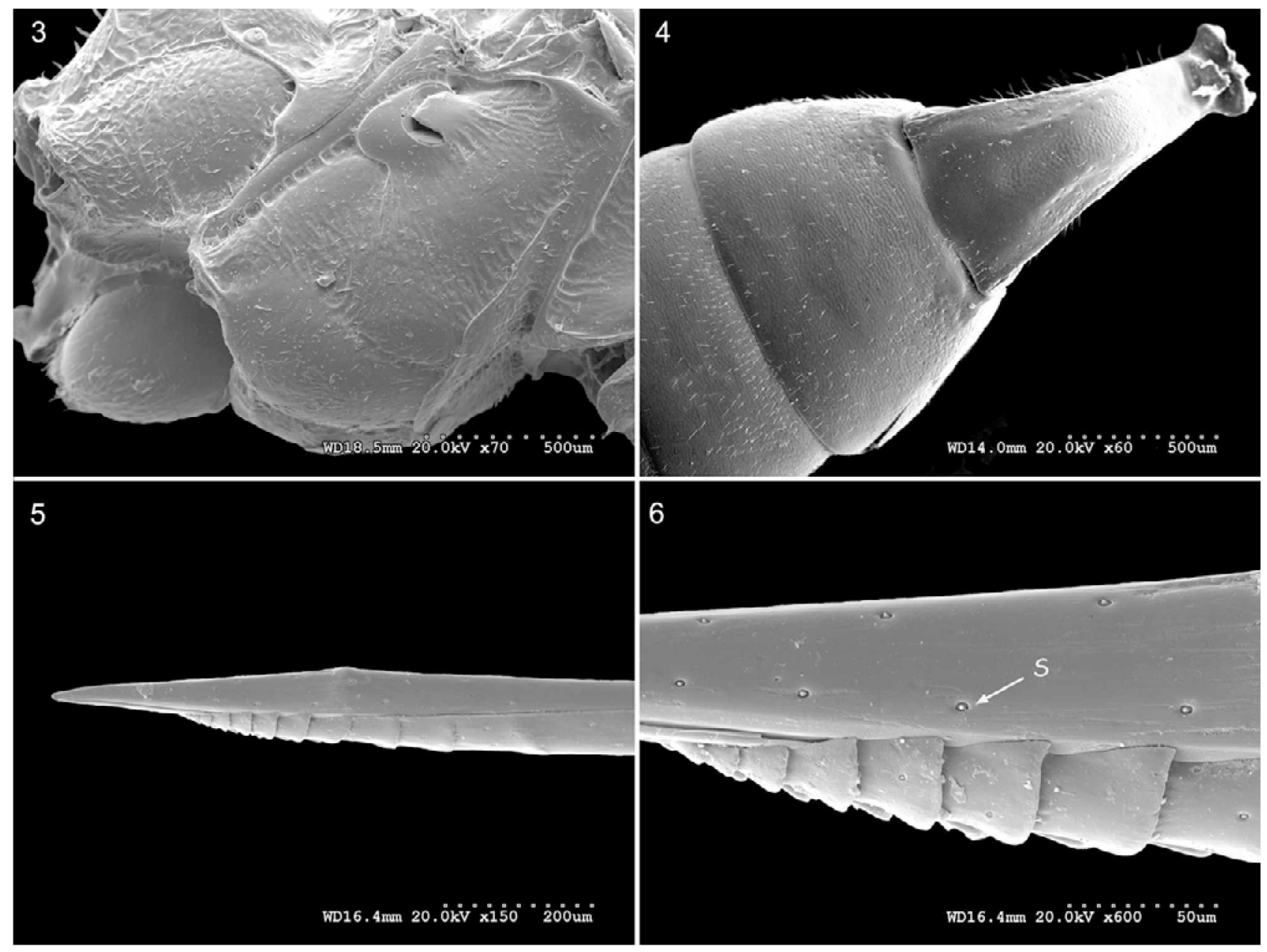

Figs 3-6: Morphology of the thorax and gaster of E. dichroma. 3 - thorax, lateral view; 4 - first to third gastral terga; 5 - ovipositor tip; 6 - ovipositor sensory receptors (s).

Gaster (Figs 4-6). First gastral tergum weakly and finely granulate, the hind sublateral edge tending to be smooth and polished. Median dorsal carinae absent or weakly insinuated on petiole, becoming obsolescent on the hind half of postpetiole. Postpetiole $0.8-0.9$ times as long as its maximum width (dorsally measured); the spiracle only slightly behind the middle. Second and rest of terga coriaceous with moderately dense setiferous punctation; hind central part of the former with this punctation much more sparse. Second gastral tergum 0.6-0.7 times as long as its maximum width (dorsally measured). Thyridia small and rounded, weakly concave. Ovipositor slightly upcurved, with nodus and strong teeth on the apex of lower valve; its tip 4.0-4.3 times the maximum height at nodus (Fig. 5). Upper and lower valves with two lines of conspicuous sensory receptors (Fig. 6, s). Ovipositor sheaths 1.3-1.4 times as long as the hind tibiae.

Male. Body length 3.7-8.1 mm. Head 0.3-0.7 mm long and 0.7-1.4 mm wide. Thorax 1.1-2.4 mm long, 0.4-1.0 $\mathrm{mm}$ wide (mesoscutum). Front wing $3.1-5.9 \mathrm{~mm}$ long. Petiole $0.2-0.6 \mathrm{~mm}$ long. Postpetiole $0.2-0.5 \mathrm{~mm}$ long and $0.1-0.3 \mathrm{~mm}$ wide. Second tergum $0.4-1.0 \mathrm{~mm}$ long.

Coloration. Black. Thorax mostly (except sutures and axillary trough of mesonotum and metanotum), front and middle femora and tibiae, basal ring between base of hind femora and second trochanter, a dorsal spot on hind coxae and hind edge of gastral terga, red. Clypeus, face, cheeks, ventral half of temples, inner orbits, mandibles (except teeth), palpi, scape ventrally, front margin of pronotum, propleurum, front and middle tibiae except dorsally, which are partially black, front and middle trochanters, subtegular ridge white. Apex of scutellum and postscutellum yellow. Tegulae white to hyaline. Wings without a transverse dark band.

Description. Head (Fig. 22). Transverse, 1.8-1.9 times as wide as long. Temple $0.4-0.6$ times as long as eye. Malar space about $0.9-1.0$ times as wide as basal width of mandible. Clypeus 1.9-2.1 times as wide as long, apical margin as in female. Antennae with 25-27 segments; first flagellar segment 4.1-4.3 times as long as its maximum width; tyloids on the 11th-14th flagellar segments (Fig. 23), they have small pores opening among juxtaposed dorsal cuticular plates (Figs 24, 25), which are associated internally with cuticular ducts (Fig. 26). Flagellum with strongly protruding setae among short pubescence (Fig. 23). Genal carina joining oral carina behind base of mandible at a distance of $0.3-0.6$ times the basal width of the mandible. Hind ocelli separated from eye by about 

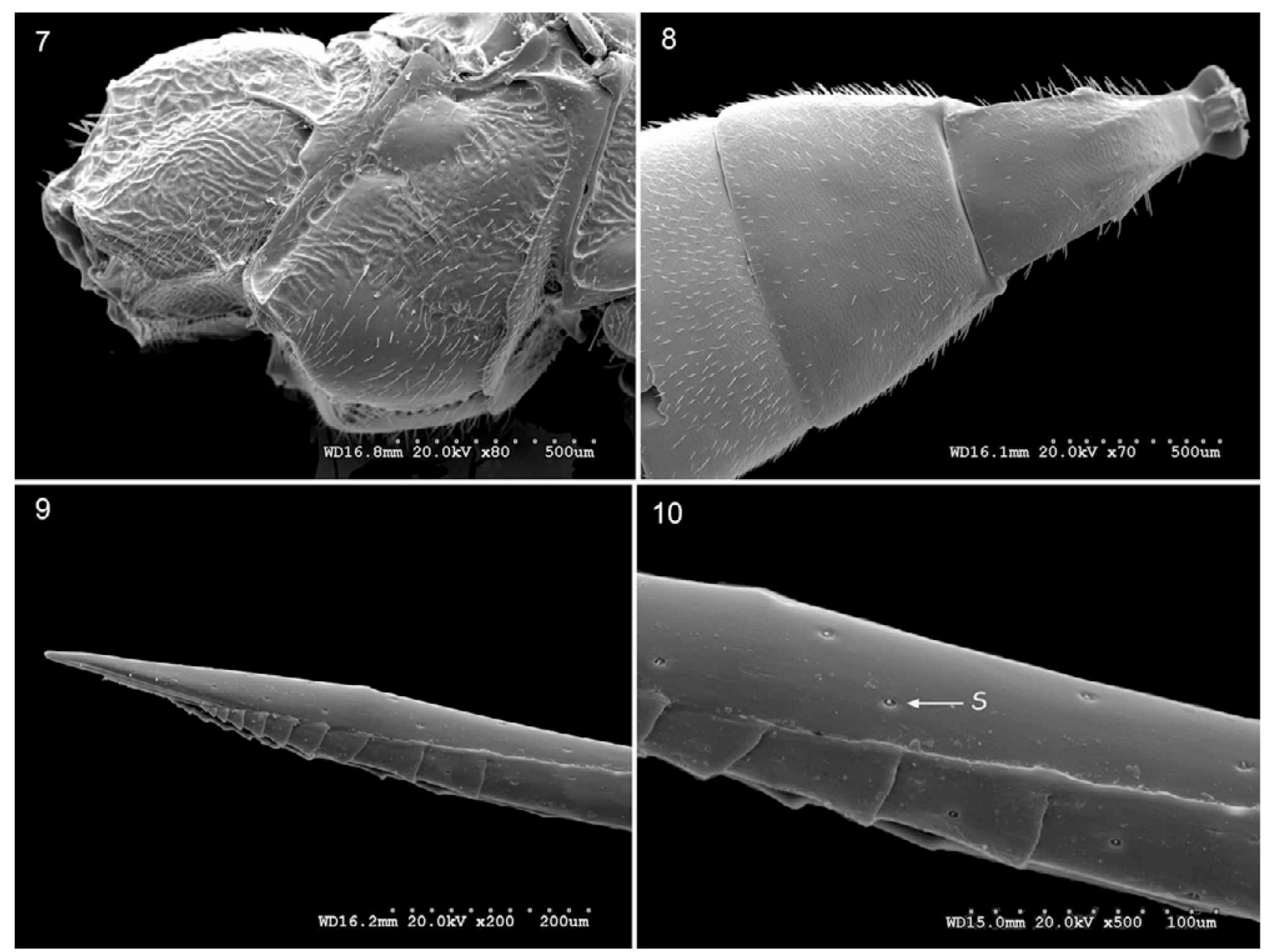

Figs 7-10: Morphology of the thorax and gaster of E. schwarzi. 7 - thorax, lateral view; 8 - first to third gastral terga; 9 - ovipositor tip; 10 - ovipositor sensory receptors (s).

1.3-1.5 their diameter. Space between hind ocelli 1.0-1.1 times their diameter. Other features as in female.

Thorax. Ramulus absent, in a few cases slightly present at base. Radial cell 2.9-3.0 times as long as its maximum width. Hind femora 5.1-5.5 times as long as high. Other characters as in female.

Gaster. First gastral tergum coriaceous, the hind edge tending to be smooth and polished. Median dorsal carinae absent. Rest of gastral terga, strongly coriaceous with dense setiferous punctation. Second gastral tergum 1.8-2.2 times as long as its maximum width (seen from above). Thyridia elongated.

Type material. Holotype: 1 female, Barranco Saragutillo (Serra, Valencia, Spain), 7-20-IV-1992, leg. F. Luna (CEUA). Paratypes: same locality, 17-24-III-1992, 1 male; 24-31-III1992, 1 female, 4 males; 31-III-7-IV-1992, 1 female, 5 males; 7-20-IV-1992, 6 females, 14 males ( 1 female, 1 male MNCN, 1 female, 1 male SC); 20-IV-5-V-1992, 1 male; 5-12-V-1992, 1 male, all them leg. F. Luna.

Etymology. di (Greek), two; chromus (Greek), coloured. The species name refers to the black gaster and red head and thorax.

Habitat. Barranco del Saragutillo (Serra, Valencia) is a valley in the Porta-Coeli mountains, near the eastern Spanish coast. The minimum height of this valley above sea level is $400 \mathrm{~m}$ and its maximum $820 \mathrm{~m}$. The Malaise trap functioned in an area with cork oak, Quercus suber L. (Fagaceae), and Pinus pinaster Aiton (Pinaceae), associated with bushes of Erica scoparia L., Erica arborea L., Arbutus unedo L. (Ericaceae) and Juniperus oxycedrus L. (Cupressaceae). Other species of vascular plants present were Cistus salviifolius L., Cistus albidus L. (Cistaceae), Thymus vulgaris L., Lavandula stoechas L., Rosmarinus officinalis L. (Labiatae), Ulex parviflorus Pourret (Leguminosae) and Sedum sediforme (Jacq.) Pau (Crassulaceae).

The climate is characterised by an irregular distribution of rainfall through the year, with an average of $600-800 \mathrm{~mm}$ per year with most falling in spring and autumn. Annual mean temperatures are usually above $16^{\circ} \mathrm{C}$. Minimum temperatures under $0^{\circ} \mathrm{C}$ are occasionally recorded from December to February (Docavo et al., 1987).

Biology. This species has a clear peak of activity in spring (Fig. 1), but it is unknown whether it has another peak in autumn, like other related species. Hosts are unknown.

\section{Enclisis schwarzi sp. $\mathrm{n}$.}

(Figs 2, 7-10, 12, 16, 20, 27-30) 

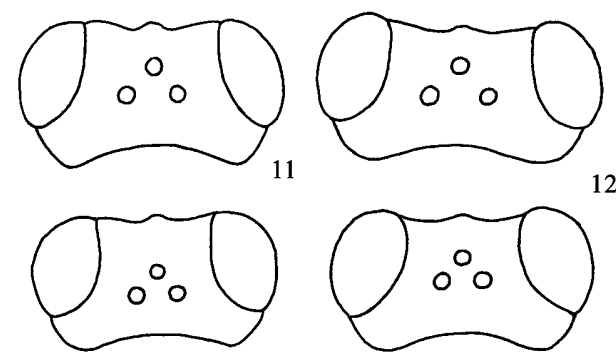

13

14
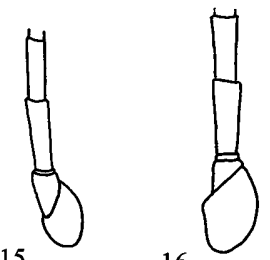

$0.5 \mathrm{~mm}$

15

16

17
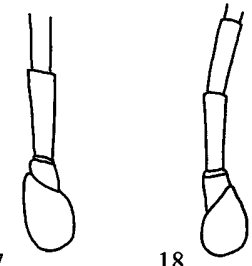

Figs 11-18: Morphology of females of Enclisis species. 11-14 - heads, dorsal view. $11-E$. infernator; $12-E$. schwarzi; $13-$ E. ornaticeps; $14-$ E. dichroma. $15-18$ - basal antennomeres. $15-$ E. infernator; $16-$ E. schwarzi; $17-E$. ornaticeps; $18-$ E. dichroma.
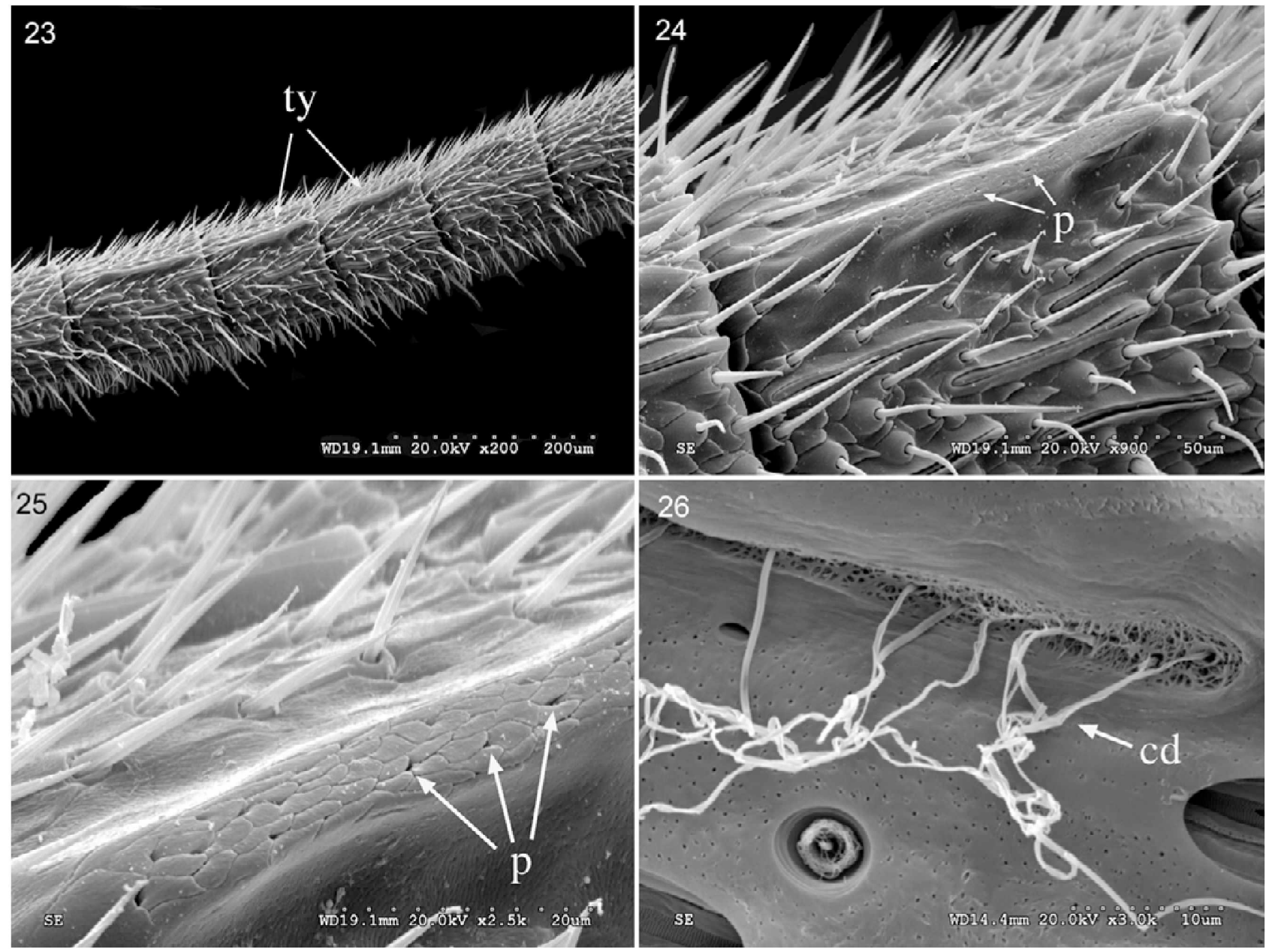

Figs 23-26: Antennal morphology of males of E. dichroma. $23-11^{\text {th }}-14^{\text {th }}$ flagellar segments showing tyloids (ty); $24-$ tyloid of $12^{\text {th }}$ flagellomere showing cuticular pores $(\mathrm{p}) ; 25$ - pores of tyloid $(\mathrm{p}) ; 26$-internal ultrastucture of tyloid showing numerous secretory cuticular ducts $(\mathrm{cd})$. 

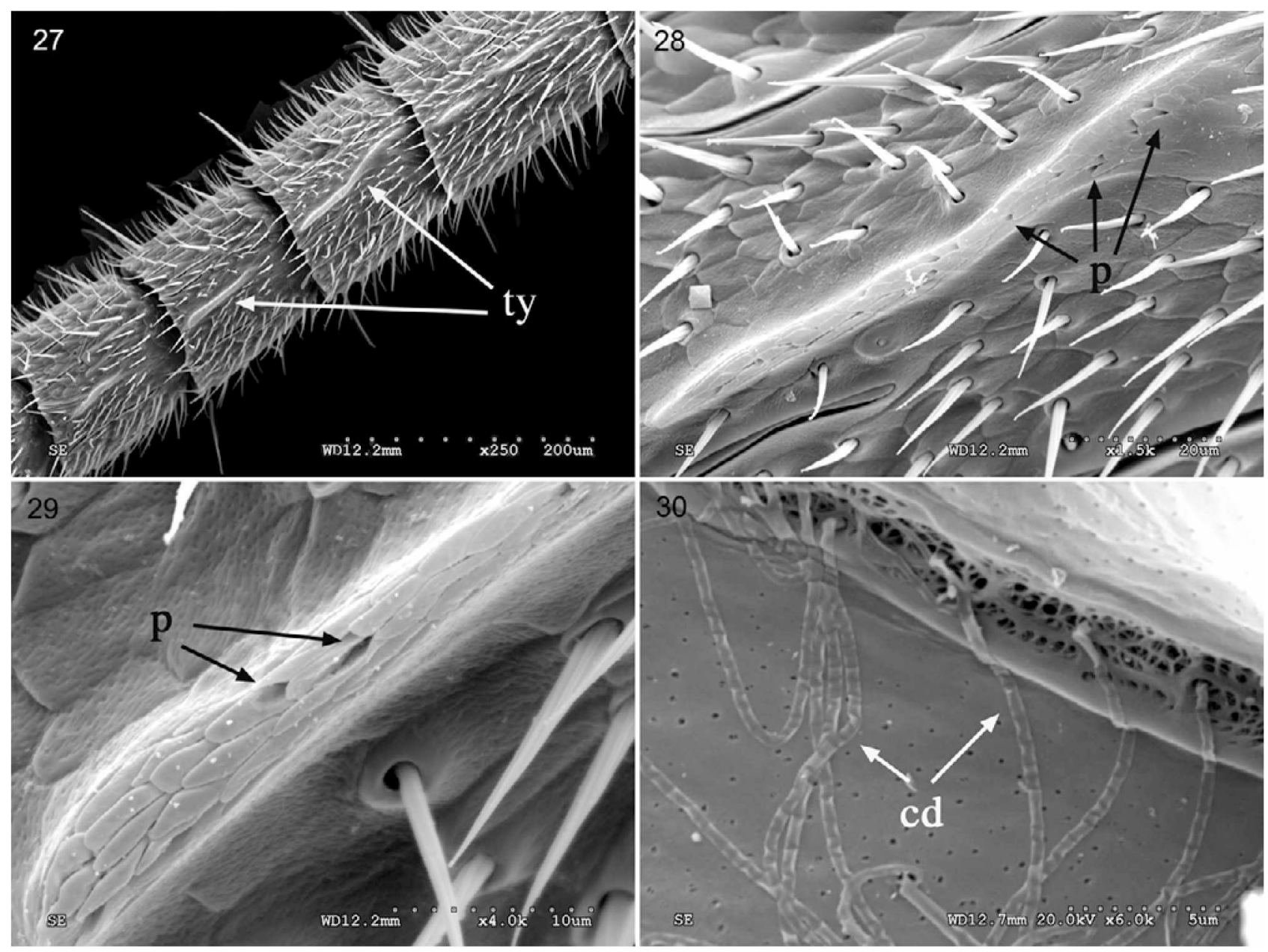

Figs 27-30: Antennal morphology of males of E. schwarzi: $27-11^{\text {th }}-14^{\text {th }}$ flagellar segments showing tyloids (ty); $28-$ tyloid of $12^{\text {th }}$ flagellomere showing cuticular pores (p); 29 - pores of tyloid (p); 30 - internal ultrastucture of tyloid showing numerous secretory cuticular ducts $(\mathrm{cd})$.

third gastral segments reddish. Palpi, distal half of front and middle femora, tibiae and tarsi light brown. Flagellum, tegula, hind tibia and tarsi brown. Antennae with a white mark dorsally on the 8th-11th flagellar segments. Seventh gastral segment with a white membrane. Wings with a transverse dark band.

Description. Head (Fig. 12). Transverse, 1.8-1.9 times as wide as long, strongly constricted behind the eyes. Temple 0.4 times as long as eye (viewed from above). Face, frons and vertex with dense punctures on granulate background. Temples with small and sparse setiferous punctures on a granulate background on the upper half, and on a smooth and polished background on the lower half. Cheeks strongly granulate with a very shallow and sparse punctation, about 1.0-1.2 times as wide as basal width of mandible. Clypeus about 2.0-2.5 times as wide as long, moderately convex, polished or sligthly granulate, with very sparse deep punctures; its apical margin straight, with sharp lateral edges and a blunt angulation on midline. Lower mandibular tooth longer than upper tooth. Antennae with 24-25 segments; first flagellar segment 2.7-3.0 times as long as wide (Fig. 16). Genal carina joining oral carina behind base of mandible at a distance $0.5-0.6$ times the basal width of the mandible. Hind ocelli separated from eye by about 2.2-2.3 times their diameter; space between hind ocelli 2.3-2.5 their diameter.

Thorax (Fig. 7). Pronotum with weak longitudinal wrinkles. Epomia present. Mesoscutum polished, sligthly granulate in the centre with weak and very sparse punctures, their interspaces twice their diameter. Notauli deep and reaching about $0.5-0.6$ the distance to scutellum, at which point they are connected by a conspicuous semicircular depression of mesoscutum. Scutellar groove with longitudinal carinae. Scutellum smooth and polished, finely punctate and without lateral carinae. Mesopleurum strongly rugose on the upper side of sternaulus, except in the area in front of the speculum where it is punctate; the background polished. Speculum smooth, polished and hairless, sometimes with a few very sparse hairs. Sternaulus sinuous, its hind end curved weakly toward base of middle coxa, only strongly distinct on $1 / 2$ the length of mesopleurum. Propodeum conspicuously rugose on a smooth or finely granulate background; first lateral areas without wrinkles and with small and sparse setiferous punctures. Both of its transverse carinae strong and com- 
plete but the apical transverse carina not forming a sublateral crest. Propodeal spiracle circular and joining pleural carina. Juxtacoxal carina strongly present at least at the base. Ramulus of fore wing absent. Radial cell 2.9-3.2 times as long as its maximum width. Second recurrent vein vertical or weakly reclivous. Areolet pentagonal. Nervulus opposite basal vein. Nervelus vertical, strongly angular and intercepted a little below the middle. Hind femora 3.6-3.8 times as long as high.

Gaster (Figs 8-10). First gastral tergum granulate. Median dorsal carinae distinct on petiole, becoming obsolescent on the hind half of postpetiole. Postpetiole as long as its maximum width (dorsally measured), the spiracle only slightly behind the middle. Second and rest of terga coriaceous with moderately dense setiferous punctation; hind central part of the former with this punctation more sparse. Second gastral tergum 0.7 times as long as its maximum width (dorsally measured). Thyridia rounded, very slightly developed. Ovipositor weakly upcurved, with nodus and strong teeth on the apex of lower valve; its tip 4.2-4.4 times the maximum height at nodus (Fig. 9). Upper and lower valves with two lines of conspicuous sensory receptors (Fig. 10, s). Ovipositor sheaths 1.1-1.2 times as long as the hind tibiae.

Male. Body length 4.8-7.1 mm. Head 0.5-0.6 mm long and $0.9-1.2 \mathrm{~mm}$ wide. Thorax 1.4-2.0 $\mathrm{mm}$ long, 0.7-0.9 $\mathrm{mm}$ wide (mesoscutum). Front wing $3.7-4.7 \mathrm{~mm}$ long. Petiole $0.3-0.5 \mathrm{~mm}$ long. Postpetiole $0.3-0.5 \mathrm{~mm}$ long and $0.2-0.3 \mathrm{~mm}$ wide. Second segment $0.6-0.8 \mathrm{~mm}$ long and $0.3-0.5 \mathrm{~mm}$ wide.

Coloration. Black. Mandibles, clypeus partially, proximal edge of femora and second trochanters, thyridia, apex of second tergum, hind half of third, usually the hind half of fourth and hind edge of fifth, reddish. Tegula white to brown. Sometimes, two spots on the frontal orbits, collar of pronotum, mandibular bases, ventral part of front and middle trochanters, yellow. Palpi, distal half of front and middle femora, tibiae and front tarsi light brown. Antennae, hind tibiae, middle and hind tarsi brown.

Description. Head (Fig. 20). Transverse, 1.8-1.9 times as wide as long. Vertex polished with very slightly setiferous punctures. Temple $0.4-0.7$ times as long as eye, polished and punctured like vertex. Malar space about $0.8-0.9$ times as wide as basal width of mandible. Clypeus 1.8-2.0 times as wide as long, apical margin as in female. Antennae with 27-28 segments; first flagellar segment 3.1-3.3 times as long as wide; tyloids on the 11th-14th flagellar segments (Fig. 27), they have small pores opening among juxtaposed dorsal cuticular plates (Figs 28, 29), these pores are connected internally to cuticular canals (Fig. 30). Flagellum with strongly protruding setae among short pubescence (Fig. 27). Genal carina joining oral carina behind base of mandible at a distance of 0.6 the basal width of mandible. Hind ocelli separated from eye by a distance of about $1.7-2.0$ their diameter. Space between hind ocelli about 1.7-2.0 times their diameter. Other characters as in female.
Thorax. Ramulus absent. Radial cell 2.6-2.9 times as long as its maximum width. Hind femora 4.5-5 times as long as high. Other features as in female.

Gaster. First gastral tergum granulate with dense setiferous punctation, the hind edge tending to be smooth and polished. Median dorsal carinae absent. Rest of gastral terga, strongly coriaceous with dense setiferous punctation. Second gastral tergum 1.6-1.8 times as long as its maximum width (seen from above). Thyridia elongated.

Type material. Holotype: 1 female, Font Roja, (Alicante, Spain), 6-20-V-1992, leg. F. Luna (CEUA). Paratypes: 21-IV-6$\mathrm{V}-1992,1$ male; 6-20-V-1992, 1 female, 8 males (1 male MNCN, 1 male SC); 20-V-3-VI-1992, 1 male; 26-VIII-9-IX1992, 9 males; 24-IX-8-X-1992, 1 female, 1 male; all them leg. F. Luna.

Etymology. This species is dedicated to Dr. Martin Schwarz (Linz, Austria) for his valuable work on taxonomy of Cryptinae.

Habitat. Font Roja is a protected mountainous area of about $1.300 \mathrm{Ha}$ in eastern Spain. The minimum height above sea level is $700 \mathrm{~m}$ and the maximum $1352 \mathrm{~m}$, the Menejador peak. The climax vegetation there is Mediterranean oak forest with Quercus ilex L. subsp. rotundifolia (Lam.) Schwartz ex T. Morais (Fagaceae), which is associated on the shady slopes with Quercus faginea Lam. (Fagaceae), Acer granatense Boiss (Aceraceae), Taxus baccata L. (Taxaceae), Sorbus aria (L.) Crantz (Rosaceae) and Fraxinus ornus L. (Oleaceae), and on the sunny slopes with Pinus halepensis Miller (Pinaceae), Quercus coccifera L. (Fagaceae), Ulex parviflorus Pourret, Genista scorpius (L.) DC. (Leguminosae), Juniperus oxycedrus L. (Cupressaceae) and Cistus albidus L. (Cistaceae). All specimens were collected on the sunny slopes.

The average rainfall, of $450-750 \mathrm{~mm}$ per year, in this area is irregularly distributed throughout the year, with maximums in spring and autumn. Annual mean temperatures are from 12 to $16^{\circ} \mathrm{C}$ in the lowlands and under $12^{\circ} \mathrm{C}$ in the highlands. Minimum temperatures under $0^{\circ} \mathrm{C}$ usually occur from October to May (Boronat et al., 1989).

Biology. This species seems to be bivoltine with peaks of flight activity in spring and autumn (Fig. 2). Hosts are unknown.

\section{DISCUSSION}

European species were revised, keyed and illustrated by Schwarz (1989). The new species are closely related to $E$. ornaticeps (Thomson, 1885) and E. infernator (Aubert, 1968 ) in having a polished mesoscutum with sparse punctures, smaller than the interspaces, polished and rugose mesopleurum with sparse setiferous punctures, black thorax or if reddish then the scutellum is also reddish, hind tarsi without a white ring and first flagellar segment less than five times as long as wide. Antennae of female and male with 22-26 and 25-28 segments, respectively.

The new taxa can be distinguished as follows: 


\section{Females.}

1 Thorax and head black. At most, a spot on frontal orbit, clypeus and mandibles partially, reddish. Space between hind ocelli 2.2-2.5 their diameter. Hind ocelli separated from eye by a distance of about 2.2-2.4 times their diameter (Figs 11, 12) ...................... 2

- Head and thorax mostly reddish. Scutellum always red. Space between hind ocelli $1.4-1.8$ their diameter. Hind ocelli separated from eye by a distance of about 1.5-1.9 times their diameter (Figs 13,14) . . . . . . . . . . 3

2 Gaster black, sometimes postpetiole reddish. Hind femur 4.5-4.6 times as long as deep. First flagellar segment 3.3-3.4 times its maximum width (Fig. 15) $\ldots \ldots \ldots \ldots \ldots \ldots$

E. infernator (Aubert, 1968)

- Postpetiole, second and third gastral terga red. Hind femur 3.6-4.0 times as long as deep. First flagellar segment 2.7-3.0 times its maximum width (Fig. 16) ... E. schwarzi sp. n

3 Gaster reddish, sometimes base of first tergum and from fifth to apex fuscous. First flagellar segment 2.7-3.5 times its maximum width (Fig. 17). Hind femur 4.0-4.4 times as long as deep ......... E. ornaticeps (Thomson, 1885)

- Gaster black to dark brown, sometimes postpetiole, and front and/or hind edge of second tergum reddish. First flagellar segment 3.6-3.7 times its maximum width (Fig. 18) Hind femur 4.6-4.8 times as long as deep

E. dichroma sp. n

Males.

1 Hind ocelli separated from eye by a distance of about 1.7-2.4 times their diameter. Space between them, 1.7-2.5 their diameter (Figs 19, 20). Head black, at most clypeus and mandibles reddish; sometimes a yellow spot on facial and/or frontal orbits. Coxae and trochanters mostly black ..

Hind ocelli separated from eye by a distance of about 1.3-1.5 times their diameter. Space between them 1.0-1.2 their diameter (Figs 21, 22). Head with mandibles, inner orbits, face, clypeus, cheeks and most of the temple, white Front coxae ventrally, and front and middle trochanters white $\ldots \ldots \ldots \ldots \ldots \ldots \ldots \ldots \ldots \ldots \ldots$

2 Gaster black, at most a fine line on the hind edge of terga 1-3 yellow. Hind femur 5.7-5.8 times as long as deep .... . E. infernator (Aubert, 1968)

- Hind half of third tergum of gaster and usually a wide band on the hind edge of second and most of fourth reddish. Hind femur 4.5-5 times as long as deep ..... E. schwarzi sp. n.

3 Thorax black. Scutellum and postscutellum with yellow marks. Yellow mark on face and clypeus separated from yellow inner orbits by a vertical dark band

E. ornaticeps (Thomson, 1885)

- Thorax mostly reddish (dark specimens at least with mesopleurum and metapleurum with clear red marks). Scutellum and postscutellum always red, sometimes yellowish at apex. Head mostly yellow, yellow mark on face and clypeus never separated from inner yellow orbits by a vertical dark band

E. dichroma sp. $\mathrm{n}$

An important factor in the ecology of adult Ichneumonidae is humidity. As a general rule, adult ichneumonids need to drink water daily, usually dew on the vegetation. As Ichneumonidae are dependent on dew on foliage, they are restricted to humid areas. This restriction is a general fact. The majority of species and individuals occur only where and when the rain or dew is available (Townes, 1958).
In high mountainous areas in southern Europe, and middle and northern Europe, Ichneumonidae are mainly abundant and active in summer (Horstmann, 1992; Nieves \& Rey del Castillo, 1991; Segade et al., 1997), because at this time of the year, warm days and cool nights result in the formation of dew.

In the low lands of southern Europe, dew or rain is common in spring and fall but not in the dry summers. In this area ichneumonids usually show two peaks of activity each year, in spring or early summer and in the fall, when the moisture is abundant. In summer and winter they tend to be inactive.

The new species were collected in a habitat with these climatic conditions, and therefore show a bimodal phenology like other Ichneumonidae on the eastern Spanish coast (Horstmann, 1992).

E. schwarzi and probably E. dichroma are bivoltine species, with peaks of adult abundance in spring and autumn, and they pass the dry summer season as larvae or pupae in the host nests or galleries in branches or wood.

In this study we observed a particular disposition of cuticle on the top of the tyloids in both species. This is forming juxtaposed longitudinal plates on which interstices there are distinct pores (Figs 25, 29). Internally, these pores are connected to ducts with a constant diameter of about 0.5 microns and a variable length (Figs $26,30)$.

Bin et al. (1999) found similar structures in males of the ichneumonid Pimpla turionellae (Linneus, 1758) and demonstrated that these antennal tyloids, located on the 8th and 9th antennomeres, are integumentary glands involved in mating behaviour. These glands are bicellular secretory units that consist of one secretory cell and one canal cell forming an evacuating cuticular duct that connects the secretory cell with the external pores on the tyloids.

The internal cuticular ducts in $E$. dichroma and $E$. schwarzi correspond to the evacuating canals of the tyloid secretory glands described by Bin et al. (1999) in Pimpla turionellae. The ultrastructural features of the tyloids in Enclisis species, support the hypothesis of Isidoro et al. (1996) and Bin et al. (1999) that they have a secretory role. Further studies on Ichneumonidae tyloids are needed to demonstrate that this is a general feature of the group.

ACKNOWLEDGEMENTS. We are grateful to Martin Schwarz, Biologiezentrum des oö. Landesmuseums (Linz, Austria), who revised material and made valuable taxonomic comments. Our special thanks to the curators of the collections at the Laboratory of Entomology of Wageningen University (The Netherlands), Musée Zoologique (Lausanne, Switzerland), Museum of Natural History of Wroclaw University (Poland), Museum of Zoology of Lund University (Sweden), Natur-Museum Senckenberg (Frankfurt, Germany) and The Natural History Museum (London, United Kingdom) for the loan of Enclisis type material from the collections in their care.

This research was supported partially by Projects BOS20000148 and AGL2000-0342-P4-02 from Ministerio de Ciencia y Tecnología (D.G.I.) of Spanish Government. 


\section{REFERENCES}

Bin F., Wäckers F., Romani R. \& IsIDORo N. 1999: Tyloids in Pimpla turionellae (L.) are release structures of male antennal glands involved in courtship behaviour (Hymenoptera: Ichneumonidae). Int. J. Insect Morphol. 28: 61-68.

Boronat J., Lancis C., Fresneda M. \& Mansanet C. 1989: Protección del Medio Físico de la Font Roja. Instituto de Cultura "Juan Gil Albert", Diputación de Alicante, Alicante, 124 pp.

Docavo I., Aguilella A., Baixeras J., González P., Jiménez R., Michelena J., Oltra M.T., Pardo J., Ribes J., Sáiz J., Sendra A. \& Tormos J. 1987: La Entomofauna del Monte de PortaCoeli. Edicions Alfons el Magnanim, Institució Valenciana d'Estudis i Investigació, Valencia, 188 pp, 28 pls.

EADY R.D. 1968: Some illustrations of microsculpture in the Hymenoptera. Proc. R. Entomol. Soc. London 43: 66-72.

FrILl F. 1974: Studi sugli Imenotteri Icneumonidi. V. I "Phygadeuon" della collezione Gravenhorst. Mem. Soc. Entomol. Italiana 53: 97-193.

GAUld I. 1991: The Ichneumonidae of Costa Rica, 1. Mem. Am. Entomol. Inst. 47: 589.

Gauld I. \& Bolton B. 1988: The Hymenoptera. British Museum (Natural History), Oxford University Press, Oxford, $332 \mathrm{pp}$.

HoRstManN K. 1992: Zur Zusammensetzung und Phänologie der Ichneumoniden-Zönose eines mediterranen Habitats in Südost-Spanien (Hymenoptera). Zool. Beitr. N. F. 34: $157-166$.

Isidoro N., Bin F., ColazzA S. \& Vinson S.B. 1996: Morphology of antennal gustatory sensilla and glands in some parasitoid Hymenoptera with hypothesis on their role in sex and host recognition. J. Hym. Res. 5: 206-239.
Jonaitis V. 1990: Resources, Formation and Functioning of Host Parasite Entomocomplexes in Ecosystems. Institute of Ecology of the Lithuanian Academy of Sciences, Vilnius, 232 pp.

Nieves Aldrey J.L. \& Rey del Castillo C. 1991: Ensayo preliminar sobre la captura de insectos por medio de una trampa Malaise en la Sierra de Guadarrama (España) con especial referencia a los Himenópteros (Insecta: Hymenoptera). Ecología 5: 383-403.

Quicke D. 1997: Parasitic Wasps. Chapman \& Hill, London, $470 \mathrm{pp}$.

Schwarz M. 1989: Revision der Gattung Enclisis Townes (Hymenoptera: Ichneumonidae). Linzer Biol. Beitr. 21/2: 497-522.

Schwarz M. 1998: Eine neue Enclisis-Art aus China (Hymenoptera: Ichneumonidae: Cryptinae). Linzer Biol. Beitr. 30/1: 255-258.

Segade C., Ros-Farré P., Algarra A., Ventura D. \& PujadeVILLAR J. 1997: Estudio comparativo de las capturas realizadas con trampa Malaise en Andorra con especial atención a los Himenópteros (Hymenoptera). Zapateri Revta. Aragon. Entomol. 7: 71-82.

Townes H. 1958: Some biological characteristics of the Ichneumonidae (Hymenoptera) in relation to biological control. $J$. Econ. Entomol. 51: 650-652.

Townes H. 1970: The Genera of Ichneumonidae, Pars I. Mem. Am. Entomol. Inst. 11: 300 pp.

Received August 14, 2002; revised December 5, 2002; accepted January 7, 2003 